\title{
Adaptation of boreal field crop production to climate change
}

\section{Stoddard, Fred}

INTECHopen

2011

Stoddard , F , Mäkelä , P \& Puhakainen , T A 2011, Adaptation of boreal field crop pÿproduction to climate change . in J Blanco \& H Kheradmand (eds), Climate Change Research and Technology for Adaptation and Mitigation . INTECHopen , Rijeka, Croatia , pp. 403-430.<

http://www.intechopen.com/articles/show/title/adaptation-of-boreal-field-crop-production-to-climate-change $>$

http://hdl.handle.net/10138/28511

publishedVersion

Downloaded from Helda, University of Helsinki institutional repository.

This is an electronic reprint of the original article.

This reprint may differ from the original in pagination and typographic detail.

Please cite the original version. 


\title{
Adaptation of Boreal Field Crop Production to Climate Change
}

\author{
Frederick L. Stoddard, Pirjo S. A. Mäkelä and Tuula Puhakainen \\ Department of Agricultural Sciences, University of Helsinki \\ Finland
}

\section{Introduction}

The average annual global temperature increased by $0.76^{\circ} \mathrm{C}$ during the past century (Intergovernmental Panel on Climate Change (IPCC), 2007) and climate modelling results show an increase in annual temperature in boreal regions of $0.1-0.4^{\circ} \mathrm{C} /$ decade over the 21st century, depending on the scenario and model. Warming will be unevenly distributed, being greater in summer in lower and middle latitudes but greater in winter at higher latitudes, and this differential will increase. Mean annual precipitation is projected to increase in the North and decrease in the South, and winter precipitation will increase in northern and central Europe, continuing the trends established in the 20th century of a 10 $40 \%$ increase in northern Europe and a decrease of up to $20 \%$ in southern Europe (IPCC, 2007). The increase in winter precipitation is due to the increased water carrying capacity of the atmosphere resulting from the higher temperature.

Global warming will increase the frequency of soil freeze-thaw cycles (FTCs) in cooltemperate and high-latitude regions previously subject to prolonged winter soil frost (Kreyling et al., 2007; Henry, 2008). Warmer winters will result in fewer soil freezing days and in boreal Europe, lowland permafrost is expected to eventually disappear (Harris et al., 2009). The length of the frost-free season has already increased in most mid- and highlatitude regions of both hemispheres over the values established in the middle of the 20th century. In the Northern Hemisphere, this is mostly manifested as an earlier start to spring, which will arrive progressively earlier in Europe by $2.5 \mathrm{~d}$ per decade (Menzel et al., 2006). Increased precipitation in winter, when there is little plant growth, increases the probability of leaching, runoff and erosion from unprotected boreal soils. Climatic warming can paradoxically lead to colder soil temperatures in winter when it reduces the thickness of the insulating snow cover (Henry, 2008 and references therein) leading to root injury (Kreyling, 2010). Increased soil freezing when snow was removed led to root injury, increased leaching of C, N and P, and decreased soil microarthropod abundance (Groffman et al., 2001; Weih \& Karlsson, 2002; Henry, 2008), but it is unclear what impacts FTCs and lower soil temperature will have on soil biological and physical processes. Observed nitrate losses to the groundwater after deep soil frost events are attributable more to reduced root uptake due to root injury than to increased N net mineralization (Matzner \& Borken, 2008) (Figure 1).

The intensity and frequency of summer heat waves is likely to increase (IPCC, 2007). Between 1977 and 2000, these trends were more extreme in central and north-eastern Europe and in mountainous regions than in the Mediterranean region. Temperatures are increasing 
more in winter than summer. Furthermore, an increase in variability of daily temperatures was established during 1977 - 2000 due to an increase in warm extremes, rather than a decrease of cold extremes. Thus Nordic summers are predicted to show more frequent heat waves, while the summer rainfall comes in less frequent, heavier intervals, and the net effect for crops will be more frequent heat and drought stress.

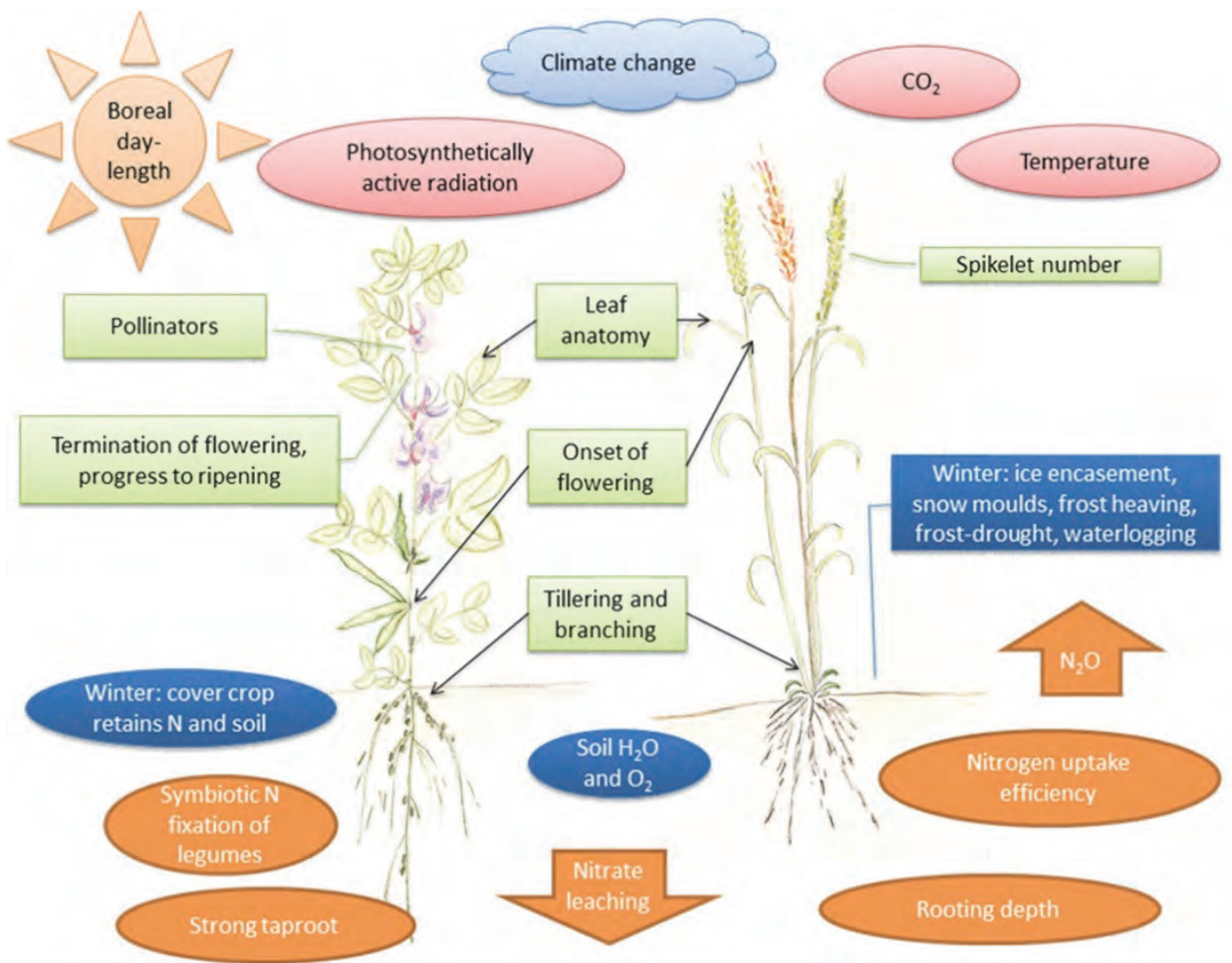

Fig. 1. Climate change alters the inputs of photosynthetically active radiation while $\mathrm{CO}_{2}$ and temperature both rise and boreal daylength is long. These factors affect leaf anatomy, branching and flower development. Indeterminate crops need to stop flowering in order to ripen in time. Autumn-sown crops are subject to several winter-related stresses. Rooting depth is important to withstand drought, and broadleaf crops usually have a strong taproot. Key aspects of the $\mathrm{N}$ cycle include nitrate leaching when snow melts, release of $\mathrm{N}_{2} \mathrm{O}$ from soil after summer rains, the use of $\mathrm{N}$-fixing legumes in the rotation, and the potential to improve $\mathrm{N}$ uptake efficiency in cereals and oilseeds to counter the increased $\mathrm{C}: \mathrm{N}$ ratio that results from the higher availability of $\mathrm{CO}_{2}$.

These cycles of wet and dry could also lead to increased releases of $\mathrm{N}_{2} \mathrm{O}$ from the soil, as the intervals of anaerobiosis following the heavy rains, combined with the warmth of the soil, increase the activity of denitrifying prokaryotes (Philippot et al., 2007). In an in situ ecosystem manipulation experiment, short-term $\mathrm{N}_{2} \mathrm{O}-\mathrm{N}$ losses slightly increased when elevated $\mathrm{CO}_{2}$ was combined with warming and drought (Cantarel et al., 2011). Potential 
management strategies include slowly released $\mathrm{N}$ sources, such as plant residues, along with rapid $\mathrm{N}$ uptake, promoted by cover crops in autumn and well managed crop stands in summer (Figure 1).

Heavy precipitation in the autumn occurring at the time of yellow ripeness and maturity will decrease the quality of grain crops by increasing alpha-amylase activity, leading to starch damage and pre-harvest sprouting, and by promoting the growth of fungi including toxin-producing Fusarium species (Porter \& Semenov, 2005; Clarke et al., 2005).

Crop physiological responses to temperature largely determine plant adaptation to different climatic zones and seasons; the level of photosynthetically active radiation and the length of the growing season determine the upper limit of productivity, and the phenological development of crops is influenced by temperature and light quality. Porter \& Semenov (2005) highlighted the non-linear relationship of photosynthesis and respiration with temperature, in contrast to the linearity of the overall rate of crop development and progression through the life cycle.

\subsection{High temperature}

Plant responses to temperature and their sensitivity to temperature changes differ during ontogeny. Growth and development are accelerated by an increase in ambient temperature up to some optimum or maximum, whereafter rates decrease again. Generally crops are more sensitive to temperature changes at generative than at vegetative stages. In oilseed rape (Brassica napus L. ssp oleifera (DC.) Metzg.), high temperature resulted in shorter and thinner stems, smaller and thicker leaves, and also decreased stomatal conductance and thus transpiration (Qaderi et al., 2006). These morphological and anatomical changes could explain the decrease in plant biomass. High temperature during seed filling resulted in reductions in seed yield and oil content in this species, with strong differences among cultivars in the ability to adapt to a gradual increase in temperature (Aksouh et al., 2001).

Porter \& Gawith (1999) divided the temperature responses of cereals based on four different developmental stages: sowing, terminal spikelet initiation, anthesis and grain filling. At the time of sowing, the soil temperature should be above $5^{\circ} \mathrm{C}$, whereas optimum air temperatures range from 20 to $24^{\circ} \mathrm{C}$. Winter crops are mainly sown when average air temperatures are already suboptimal, below $16^{\circ} \mathrm{C}$, so an increase in autumn temperatures would not be detrimental to crop development or yield formation (Porter \& Gawith, 1999). The sowing temperature has a marked role especially in crops that require vernalization before flowering. In the worst case, temperatures over $21^{\circ} \mathrm{C}$ after vernalization fulfilment may reverse the vernalization process and hinder flowering, as shown in meadow fescue (Festuca pratensis Huds.) (Heide, 1988). Base temperatures for vernalization range from $-1.3^{\circ} \mathrm{C}$ to $15.7^{\circ} \mathrm{C}$ and in wheat (Triticum aestivum L. emend Thell.), spikelet initiation begins above $1.5^{\circ} \mathrm{C}$ and deteriorates above $25^{\circ} \mathrm{C}$. Floret, pollen and grain sterility increase when temperatures decrease below $9^{\circ} \mathrm{C}$ or exceed $31^{\circ} \mathrm{C}$ during early stages of anthesis (Porter \& Gawith, 1999), so the major yield component affected by high temperature is harvest index due to decreased grain number (Porter \& Semenov, 2005). The grain filling stage is the most resistant to changes in temperature, the main effect usually being on starch synthesis (Porter \& Gawith, 1999). The occurrence of high temperature during grain filling and drought during stem elongation has decreased wheat yields in France (Brisson et al., 2010). An increase in night temperature has been found especially detrimental for grain filling processes (Prasad et al., 2008). 
Root growth is even more sensitive to temperature changes than shoot growth. Root growth responds to diurnal temperature changes in the upper soil layers. The optimal temperature for root growth seems to be around $20^{\circ} \mathrm{C}$, whereas under $2^{\circ} \mathrm{C}$ and above $35^{\circ} \mathrm{C}$ root growth is reduced or stopped, and roots die under $-20^{\circ} \mathrm{C}$ (Porter \& Gawith, 1999). However, when Patil et al. (2010) tested the effect of soil warming by $5^{\circ} \mathrm{C}$, no significant difference was observed in wheat grain yield, even though the crop growth period was shortened by 12 days. Since the developmental stage in cereals is determined by the apex, soil warming might affect the developmental rate only when the apex is close to the soil surface (Patil et al., 2010).

Flowering needs to occur in the window between risk of late spring frosts and risk of summer heat, both of which affect ovule and pollen viability and embryo growth. An adjustment to flowering date needs to be compensated by a corresponding adjustment to the grain-filling period, in order to allow timely harvest while maintaining the duration of light interception. If earlier-flowering cultivars are selected, the risk of low temperatures during spring can cause yield reductions by slowing growth (Figure 2A), affecting fertility, or killing the young plants (Figure 2B). When frost occurs during the flowering time of winter rye or another cereal with a determinate growth habit, the harvest fails.

Pests and pathogens decrease yield either by depressing the formation of reproductive branches and hence reducing both photosynthetic green area and grain number, or by destroying the photosynthetic green area and thus decreasing energy capture (Duveiller et al., 2007). In rainfed systems, such as Nordic areas, where short periods of drought are common, soil-borne pathogens are frequent. Increasing temperatures, irregular precipitation together with longer growing season will add to the risks of severe infestations of pathogens in boreal agriculture (Luck et al., 2011).

\subsection{Drought}

Drought, a temporary inadequacy of water supply to a plant, is widely considered the main limitation to crop yields (Boyer, 1982). Spring drought is already a part of the cropping season in many Nordic regions, restricting imbibition and establishment of spring-sown crops, and affecting the formation of generative organs of cereals, since the change from vegetative to generative stage occurs early, close to the two-leaf stage. Thus, the number of sterile florets and abortion increases in cereals. These changes are irreversible and decrease the final yield. Transient summer drought is predicted to increase and drought resistance of the cool-temperate crops suitable to the boreal region is important. The effects of drought are mainly due to limitation of gas exchange until relative water content is reduced to a certain point, after which biochemical changes become more important. Net photosynthesis of turnip rape (Brassica rapa L. ssp. oleifera (DC.) Metzg.) (Mäkelä et al., 1999b) and oilseed rape (Qaderi et al., 2006) decrease under drought conditions, due to stomatal closure and metabolic impairment of photosynthetic tissues.

Oilseed rape adjusts readily to prevailing growing conditions through morphological and anatomical changes. Water deficit causes reductions in its stem height and diameter as well as in leaf number and area and thus, in total dry matter (Qaderi et al., 2010). Droughtstressed oilseed brassicas form short, thick roots that, after rewatering, rapidly elongate, exploring large soil volumes (Deleens et al., 1989; Mäkelä et al., 1999a). Water deficit also increases the amount of epicuticular wax in oilseed rape (Qaderi et al., 2010).

Sugar beet (Beta vulgaris var. altissima L.) root biomass and sugar content were reduced approximately $20 \%$ under transient drought stress developed at an early growth stage, due 
to decreases in leaf life span and net photosynthesis, but plants recovered from the stress rather quickly and almost completely (Monti et al., 2007).

Elevated $\mathrm{CO}_{2}$ can override some of the yield decreasing effects of drought. The water status of barley (Hordeum vulgare L.) under drought conditions was better under elevated $\mathrm{CO}_{2}$ than in ambient $\mathrm{CO}_{2}$, on account of the decrease in stomatal conductance under elevated $\mathrm{CO}_{2}$ (Robredo et al., 2010). In elevated $\mathrm{CO}_{2}$, photosynthesis was, surprisingly, also stimulated more under drought than under well watered conditions, and photorespiration decreased. The electron transport chain and utilization of ATP and NADPH were stimulated by elevated $\mathrm{CO}_{2}$, thus making them more tolerant to water deficit, and photoinhibition decreased (Robredo et al., 2010).

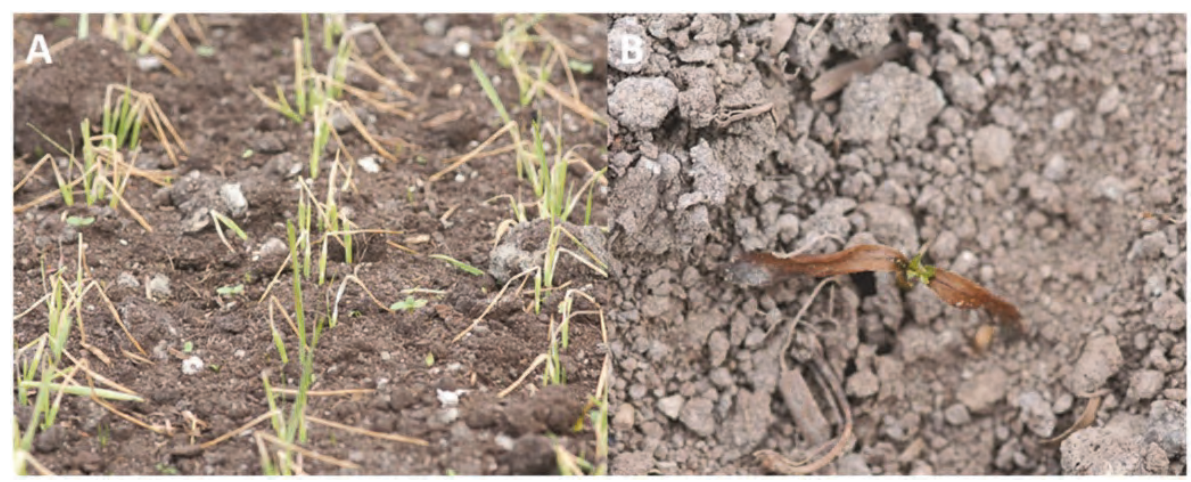

Fig. 2. Spring frosts damage crops at early growth stages. A, spring barley leaves are damaged by spring frost, decreasing the photosynthetic leaf area and slowing biomass accumulation. The apical meristem is at this stage below soil surface and does not get damaged. B, the apical meristem of sugar beet is sensitive to frost and sometimes the seedlings die, as shown around the surviving seedling in the picture

\subsection{Waterlogging}

The expected increase in autumn and winter precipitation in the boreal zone will increase the incidence of waterlogging, which will affect the overwintering ability of winter crops, although waterlogging damage is more severe, around $70 \%$ yield decrease, at $25^{\circ} \mathrm{C}$ than at winter temperatures (Luxmoore et al., 1973).

Oxygen deficiency is typical for both ice encasement and waterlogging, since the plants consume $\mathrm{O}_{2}$ while entry of $\mathrm{O}_{2}$ is prevented. Thus, metabolic anoxia tolerance plays a major role in short-term anoxia, whereas in long-term anoxia, aerenchyma formation is important. The central strategy for the plant is coping with the energy crisis (reviewed in Colmer \& Voeseneck, 2009), and although the soil is in a reducing state, waterlogging itself results in oxidative stress (Blokhina \& Fagersted 2010). In overwintering plants, often the problem is starvation during winter when the $\mathrm{C}$ reserves are utilized. Timothy (Phleum pratense L.) maintains higher $\mathrm{C}$ reserves than, for example, lucerne (Medicago sativa L.), red clover (Trifolium pratense L.) and cocksfoot (Dactylis glomerata L.), and this is considered one of its survival strategies (Bertrand et al., 2003).

Winter waterlogging in wheat decreased the size of the root system and leaf area as well as grain yield due to decreased number of spikes per plant, since the number of tillers 
produced was reduced (Dickin \& Wright, 2008; Dickin et al., 2009). Winter waterlogging also decreased the supply of nitrogen to the shoot in the early spring. This was later seen as decreased grain protein content at maturity and slightly delayed development of shoot, spikes and maturity (Dickin \& Wright, 2008). The reduced size of the root system and leaf area limits the ability of the crop to take up nutrients and intercept radiation, and later, make it more vulnerable to drought. The root system is restricted since the nodal roots located in the top $20 \mathrm{~cm}$ of soil are predominant, whereas the seminal roots located at deeper soil layers are killed due to waterlogging (Dickin et al., 2009). Thus, waterlogging is even more detrimental to yield potential than drought, and reduced canopy density during winter months could enhance formation of tillers and nodal roots, which could play an important role in yield formation in waterlogged conditions (Dickin \& Wright 2008).

Sairam et al. (2008) proposed that reactive oxygen species (ROS) and nitric oxide (NO) have messenger roles in the waterlogging stress response in plants. Formation of NO could be related to maintenance of ATP levels and energy charge, providing time for development of adventitious roots (Sairam et al., 2008), since roots can only form aerenchyma within the first $100 \mathrm{~mm}$ of growth (Dickin \& Wright, 2008). Moreover, NO could be involved in aerenchyma formation in waterlogged roots by means of apoptosis (Sairam et al., 2008).

\subsection{Carbon dioxide}

The $\mathrm{CO}_{2}$ concentration in the atmosphere is well known to be increasing, being at the moment 394 ppm (May 2011, http://co2now.org/) and predicted to increase to $700 \mathrm{ppm}$ at the end of the century (IPCC, 2007). While $\mathrm{CO}_{2}$ is considered as a greenhouse gas that contributes to climate change, it is also essential for photosynthesis and hence plant growth. Numerous Free-Air $\mathrm{CO}_{2}$ Enrichment (FACE) experiments around the world have tested hypotheses on the effects of altered $\mathrm{CO}_{2}$, in conjunction with other stresses, on the growth of various plants. In general, elevated $\mathrm{CO}_{2}$ stimulates photosynthetic carbon gain and net primary production over the long term, despite increasing the saturation of Rubisco (Ribulose-1,5,-bisphosphate carboxylase/oxygenase) and the intracellular $\mathrm{CO}_{2}$ concentration increases due to smaller stomatal aperture (reviewed in Haverkort \& Verhagen, 2008). High $\mathrm{CO}_{2}$ down-regulates Rubisco activity in $\mathrm{C} 3$ plants (including wheat, oilseed brassicas, and legumes) that are the main crops in the boreal region, stimulates dark respiration via transcriptional reprogramming of metabolism, and decreases photorespiration (reviewed in Leakey et al., 2009). The photosynthesis of C3 plants, such as potato (Solanum tuberosum L.), however, acclimatizes to elevated $\mathrm{CO}_{2}$, which results eventually in reduction in Rubisco content (Haverkort \& Verhagen, 2008; Leakey et al., 2009). Even though assimilation is stimulated, partitioning is not, and yield increases are sink-limited unless additional $\mathrm{N}$ is supplied (Leakey et al., 2009). Elevated $\mathrm{CO}_{2}$ concentration has also been shown to attenuate the effects of water deficit and to improve the efficiency of water use at both the leaf and canopy scale by maintaining the stomatal conductance, carboxylation rate and RuBP (Ribulose-1,5-bisphosphate) regeneration (Robredo et al., 2010). When the photosynthesis is limited by RuBP regeneration capacity, the increase in photosynthesis results mostly from decrease in photorespiration (Leakey et al., 2009). Even though water use efficiency (WUE) of most crops increases, this green leaf period may also lengthen, leading to an overall increase in use of water (Haverkort \& Verhagen, 2008).

Elevated $\mathrm{CO}_{2}$ increased the leaf thickness, leaf area, stomatal density and photosynthesis in potato, but decreased the stomatal conductance by reducing stomatal aperture (Lawson et 
al., 2002). Photosynthesis was increased and respiration decreased in potato in the same conditions and the decrease in respiration was attributable to the lowered protein content of the plant tissues (Fleisher et al., 2008). Moreover, the majority of additional photosynthate was partitioned to tubers and roots instead of above-ground biomass, and no marked differences were observed in the area, appearance rate, expansion rate, and senescence rate of leaves (Fleisher et al., 2008). When the irrigation rate under elevated $\mathrm{CO}_{2}$ was increased, photosynthate was partitioned more to leaves and stems, decreasing the harvest index, and this was attributable to the increased respiratory costs of increased biomass. Under elevated $\mathrm{CO}_{2}$, the increased tuber sink may play an important role in reducing the drought-induced feedback inhibition of photosynthesis. The radiation use efficiency (RUE) of potato was increased under elevated $\mathrm{CO}_{2}$ (Fleisher et al., 2006). Glycoalkaloid, citric acid and nitrate concentrations decreased while phosphorus, starch and dry matter content of tubers all increased in elevated $\mathrm{CO}_{2}$ (reviewed in Haverkort \& Verhagen, 2008). Low glycoalkaloid and nitrate content represents better product quality, but lowered citric acid content allows greater discolouration after cooking. At the same time, the higher temperature that is part of global change causes a contrasting decrease in dry matter content, and irregular precipitation can cause secondary growth of tubers.

Similarly, in oilseed rape, elevated $\mathrm{CO}_{2}$ resulted in taller plants with thicker stems and larger and thicker leaves (Qaderi et al., 2006), but there was no change in yield or seed oil content (Franzaring et al. 2008). Photosynthesis increased, as did chlorophyll fluorescence and content, contributing to the higher biomass production of plants grown under elevated $\mathrm{CO}_{2}$ (Qaderi et al., 2006). In the vegetative stage, biomass was higher in elevated $\mathrm{CO}_{2}$, particularly in old cultivars, but the difference between growing conditions disappeared at later stages, which was attributed to the lack of carbon storage (Franzaring et al., 2008).

When wheat was grown under high $\mathrm{CO}_{2}$, its photosynthetic capacity was decreased, probably due to down-regulation of Rubisco activity (Alonso et al., 2008). Elevated $\mathrm{CO}_{2}$ also increased the temperature optimum of the crop. Alonso et al. (2008) suggested that this was due to decrease of the Rubisco activation state at high temperature and concluded that in future conditions, the light-saturated photosynthesis will be limited by Rubisco, which could have explained the modest increase of the wheat yield obtained.

Hybrid cultivars have generally responded more positively than inbred lines to elevated $\mathrm{CO}_{2}$, probably due to their larger sinks, in which carbon assimilation is less restricted by feedback inhibition (Sun et al., 2009). When sink capacity is insufficient, $\mathrm{CO}_{2}$ elevation results in increased leaf carbohydrate concentration and down-regulation of photosynthesis (Leakey et al., 2009).

In contrast, the effects of elevated $\mathrm{CO}_{2}$ on $\mathrm{C} 4$ photosynthesis are small, and generally significant only in drought conditions (Leakey et al., 2009), but this group is currently of minor importance in boreal agriculture.

In order to maintain the yield response to elevated $\mathrm{CO}_{2}$, an increased supply of Rubisco is needed, and the plant's C:N ratio is increased by the enhanced supply of photosynthate (Porter \& Semenov, 2005), so improved access to $\mathrm{N}$ is likely to be important in boreal systems under climate change. Crops under elevated $\mathrm{CO}_{2}$ required more $\mathrm{N}$ than those under current ambient levels in order to produce optimum yield (Sun et al., 2009). Elevated $\mathrm{CO}_{2}$ reduces $\mathrm{N}$ use efficiency, lowering the protein content of cereal grains and the rheological properties of wheat flour (Porter \& Semenov, 2005), and it reduces the assimilation of nitrate in the shoots of both wheat and Arabidopsis (Bloom et al., 2010). Integration of agronomy, 
physiology, genetics and omics is necessary to identify novel ways to improve NUE of cereals and oilseeds in order that yield is maintained at lower $\mathrm{N}$ input levels or higher C:N ratios. Manipulation of glutamine synthase genes in maize had significant impacts on grain yield, whereas the genes underlying variation in root length, branching and soil volume exploration remain harder to identify and hence manipulate (Hirel et al., 2007). Strategies to improve the $\mathrm{N}$ economy of wheat, and applicable to other non- $\mathrm{N}$-fixing crops, include maximizing $\mathrm{N}$ capture through effective root morphology, optimizing $\mathrm{N}$ uptake and assimilation by activity of glutamine synthetase and other enzymes, and optimizing $\mathrm{N}$ partitioning to grain by remobilizing stem $\mathrm{N}$ while maintaining leaf photosynthetic activity and $\mathrm{N}$ content with stay-green mutations (Foulkes et al., 2009).

The enhanced availability of photosynthate resulting from high atmospheric $\mathrm{CO}_{2}$ concentration has been shown to increase $\mathrm{N}$ fixation in several legume species, so grain quality and protein content are generally maintained (Rogers et al., 2009), but there is weak evidence for this in some of the cool-temperate adapted species grown in the boreal region. Doubled $\mathrm{CO}_{2}$ concentration $(700 \mathrm{ppm}$ instead of $350 \mathrm{ppm}$ ) resulted in higher photosynthetic water use efficiency in faba bean (Vicia faba L.), the increase depending on cultivar (Avola et al., 2008), and occurring only when the water supply was not limiting (Wu \& Wang, 2000) and when solar UV-B irradiance was not increased (Tosserams et al., 2001).

The increased $\mathrm{C}: \mathrm{N}$ ratio from elevated $\mathrm{CO}_{2}$ concentration has implications for hay and silage cropping (Porter \& Semenov, 2005), which are important components of boreal agricultural systems, and adequate protein content is a key factor determining forage quality.

$\mathrm{CO}_{2}$ concentration is understood to have little or no direct effect on phenology (Craufurd \& Wheeler, 2009). Nevertheless, at elevated $\mathrm{CO}_{2}$, stomatal conductance is often reduced, so the canopy and tissue temperature increase, resulting in a thermal influence on phenological development. The apical meristem is the developing organ and it is the temperature nearest the apical meristem that affects the development (reviewed in Craufurd \& Wheeler, 2009). In spring wheat, no changes in phenological development, rate of leaf emergence or final leaf number were observed following elevation of $\mathrm{CO}_{2}$, but the number of shoots per plant and leaf area index were increased over 10\% (Ewert \& Pleijel, 1999).

Elevated $\mathrm{CO}_{2}$, together with other global change factors, affects crop architecture and flowering time in a variety of ways. Tillering of wheat increased in response to elevated $\mathrm{CO}_{2}$, with an old, tall cultivar being significantly more responsive than a young, semidwarf one (Ziska, 2008). The result was that the yield superiority of the modern cultivar disappeared at high $\mathrm{CO}_{2}$ (Ziska, 2008). Depending on the species and cultivar, flowering time has shown accelerated, unchanged, and delayed responses to elevated $\mathrm{CO}_{2}$ (reviewed by Springer \& Ward, 2007). The primary mechanism involved is not known, but involvement of carbon metabolism has been suggested (Springer \& Ward, 2007), because of its effect on flowering time (Rolland et al., 2002).

\section{Consequences for agriculture}

Climate change will lead to the intensification of agriculture in northern Europe and other boreal and nemoral zones. For example, it will lead to shifts in the northern limits of areas thermally suitable for the cultivation of soya bean and grain maize by several hundred kilometres, and lengthen the northern European growing season by 3-12 weeks by 2085, with a stronger effect at the end than at the start of the growing season leading to substantial increases in biomass production (Carter, 1998; Fronzek \& Carter, 2007). Thus these regions are 
predicted to gain many benefits from climate change, as the areas suitable for crop production will expand and new crops can be introduced to production. Some of the greatest temperature increases are expected in the Nordic region. While this will reduce some incidences of chilling, it will increase the occurrence of heat stress episodes, to which current cultivars are not adequately tolerant. The increases in $\mathrm{CO}_{2}$ concentration are expected to be beneficial to the crops with C3 metabolism that provide the basis for high-latitude agriculture, as long as temperatures remain in the moderate range that is predicted. The impacts on autumn-sown crops are more geographically variable. Yield is expected to strongly decrease in most southern areas, and increase in northern or cooler areas (e.g., wheat: +3 to $+4 \%$ by $2020,-8$ to $+22 \%$ by $2050,-15$ to $+32 \%$ by 2080 ) (Olesen et al., 2007; IPCC, 2007).

The more uneven distribution of rainfall predicted by the models (Section 1), with longer droughts in the spring, heavier and less frequent downpours in summer, and more rain in autumn and winter with less snow cover, will decrease potential crop productivity, and more attention will need to be paid towards these factors and crop responses to them. The changes in temperature and rainfall patterns will bring an increased risk of pest attacks limiting or destroying the crop production. Plants can, however, adapt to the environment. The responses of plants to the environment influence the development of new cultivars, new cropping systems and crop management practices.

The phenology, or timing of growth, of the crop determines how much light it can intercept and thus the potential biomass accumulation. The phenology of modern crops is fitted to their growing environment; that is, different developmental stages occur at appropriate times, so oilseed crops or small grain cereals flower in midsummer rather than too soon or too late. The rates of developmental processes and growth are determined by temperature, and in some cases daylength. The threshold temperatures and rates of response to changing temperature differ according to the developmental processes, plant species, and often cultivar (reviewed in Porter \& Gawith, 1999). Therefore, concepts such as growing degree days have been found useful for describing, modelling, and predicting crop growth. Growth and development are quantitative responses to temperature affected also by flux of carbon gains and losses (Porter \& Gawith, 1999).

Crop growth is affected by genotype, environment and management practices, and the environmental factors include temperature, daylength, radiation, nutrient and water availability, and $\mathrm{CO}_{2}$ concentration. Late spring and early autumn frosts limit boreal crop production, and climate change is not expected to alter this situation markedly, so there is limited scope for increasing crop yields in the future by extending the growing period.

The drawback for winter crops in boreal conditions has been poor overwintering, the main reason for which is not inadequate frost resistance but damage caused by pathogenic fungi (Microdochium spp., Fusarium spp., Typhula spp., and Sclerotinia spp.) that damage the crops during winter months under thick and long-lasting snow cover (Figure 3) when the soil temperatures are $0-5^{\circ} \mathrm{C}$. Sometimes the plant stand is almost completely lost (Jamalainen, 1974). Moreover, ice encasement, frost-drought and frost-heaving as well as waterlogging can destroy overwintering plant stands. When snow cover lasts for several months without soil freezing, winter cereals in particular can die from starvation, as plants respire throughout the winter under the snow cover, utilizing carbohydrate reserves (Jamalainen, 1978). Since the duration of permanent snow cover has been forecast to shorten, the importance of snow mould should decrease, even though the rainy autumn and winter days that promote the disease are forecast to increase. Good management practises, such as timely sowing, appropriate fungicide applications, and avoidance of too dense canopies in the autumn will 
further decrease the incidence of snow mould. Good frost hardiness is already available in a range of winter-annual crops, including rye, wheat (Hömmö, 1994), turnip rape (Mäkelä et al., 2011) and faba bean (Link et al., 2010), so winter damage due to cold temperatures will be less frequent in future, but resistance to the other stresses needs to be improved.

\section{Phenological changes due to climate change}

Phenological change as a response to climate warming has been documented in crop plants and natural communities across the northern hemisphere (Walther et al., 2002; Parmesan \& Yohe, 2003; Menzel et al., 2006; Estrella et al., 2007). The advances in timing of spring events, including earlier flowering, maturity, leaf unfolding, budburst, shooting, closure of the stands, and ear formation, correspond to patterns of human-induced climate change (Rosenzweig et al., 2008). The mean temperature of the month preceding onset was shown to have the most predictive value for timing, with effects also from the second preceding month and the month of onset (Menzel et al., 2006). Changes in timing of farm activities, including drilling, tilling, harvesting, were also strongly correlated with changes in temperature (Menzel et al., 2006).

Temperature, together with photoperiod, is a seasonal cue and a major determinant of the rate of plant development, and warmer temperatures that shorten developmental stages of determinate crops will lead to reduction of the yield. The optimal temperature for most crop plants in boreal agriculture is below $25^{\circ} \mathrm{C}$ (Porter \& Gawith, 1999; Porter \& Semenov, 2005) and this value will be exceeded more often in the future, warmer climate than it is now. Crop physiological responses to temperature largely determine their adaptation to different climatic zones and seasons; the level of photosynthetically active radiation and the length of growing season determine the upper limit of productivity, and the phenological stage of a crop is influenced by temperature and by light quality. Daylength has a further impact on development and as it increases in spring it can determine the transition from the vegetative to the reproductive phase. At the start of the high-latitude growing season, daylength is already longer than the critical value for many cultivars developed at lower latitudes. In cereals, this vegetative-reproductive transition limits biomass production, since there is no further vegetative development, whereas in pasture crops and other species with indeterminate habit, vegetative growth continues.

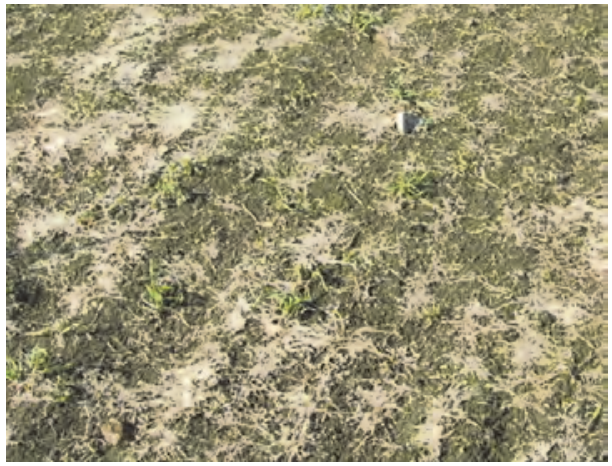

Fig. 3. Winter damage in rye. Snow mould kills the overwintering plants under snow cover and sometimes hardly any plants survive. (Antti Tuulos) 
Autumn sowing in the boreal zone is currently restricted by the onset of autumn rains that make agricultural practices difficult. Autumn-sown crop establishment occurs during a period of cooling soil and air temperatures and shortening day length. Wetter, warmer autumn conditions are therefore likely to continue to restrict sowing, but to allow crops to develop further than they do now before the onset of winter, and thus to be at greater risk of winter damage. The effect of increased autumn temperatures on vernalization has not been studied, but clearly hardening will be delayed. Changes in timing of the emergence and establishment of autumn-sown crops (which are related to harvesting and subsequent drilling) are little related to temperature (Menzel et al., 2006).

The genetic and environmental moderation of the timing of flowering, by determining the season length, and hence the availability of radiation, water and nutrient resources for growth, and by affecting the exposure of the crop to climate extremes, is therefore central to the success of the crop.

\subsection{Biomass production}

The intensity and daily duration of solar radiation varies depending on elevation and latitude. At high latitudes, solar radiation has a high red content, on account of the lower angle of the sun in the sky, even in midsummer. Cloud further decreases the amount of available radiation. Thus only part of the incident radiation is intercepted by plants and available for photosynthesis (Sinclair \& Muchow, 1999), particularly at high latitudes. Intercepted solar radiation is linearly related to dry matter accumulation. The level of solar radiation also defines the optimum leaf area index (LAI) (Stern \& Donald, 1961). An earlier developing and later maturing crop thus has the potential to capture and utilize the radiation for a longer period, within the limits set by the risks of cold temperatures in the spring and autumn. Extreme temperatures, even though not yet harmful, increase the respiration of the crops and thus limit biomass accumulation. Primary production is determined by a function of available incident solar radiation across the season, the efficiency of light interception by the crop and the efficiency of conversion of absorbed energy into biomass (Sun et al., 2009). This last step, the RUE, is affected by crop developmental stage, leaf tissue structure, and location (level of solar radiation and diffuse radiation), and through photosynthesis temperature as well as $\mathrm{N}$ and water availability. However, RUE is almost insensitive to latitude and LAI. Leaves with a high $\mathrm{N}$ content have high photosynthetic activity and RUE, which is saturated at certain leaf $\mathrm{N}$ levels depending on species. Since water deficit affects photosynthetic activity, RUE is dependent on the severity of water deficit (Sinclair \& Muchow, 1999).

RUE varies among species and developmental stages since there are differences in biochemical components of the plant products and in photosynthesis. During early stages of crop establishment when the photosynthetic capacity of the leaves is still limited, RUE is usually lower than at later stages. In potato producing starch-containing tubers forming early in the season, the conversion of photosynthate to starch can be higher than $0.83 \mathrm{~g}$ carbohydrate per $g$ photosynthate, whereas in wheat it is 0.71 . Wheat grains that develop later in the season contain up to $14 \%$ protein formed from $\mathrm{N}$ that is translocated from leaves. Species with C4 photosynthesis have generally higher RUE than C3 species, while legumes that use some energy for symbiotic nitrogen fixation have lower RUE than other crops. Interestingly potato has almost as high RUE when vegetative as maize, and the RUE is rather stable throughout the growing season (reviewed in Sinclair \& Muchow, 1999). Careful analysis of RUE could reveal the growth- and yield-limiting factors that could be 
improved by management practises and breeding in an attempt to maximize biomass for partitioning into yield. RUE levels can increase as total radiation level decreases, and in those conditions there is usually an increased proportion of diffuse radiation, so RUE is further enhanced (Sinclair \& Muchow, 1999).

Increased rooting depth and specific leaf area (SLA) could affect yield positively in warmer climates (Ludwig \& Asseng, 2010). Increased rooting depth can be an advantageous trait under rising temperatures when crop demand for water is increased. Increased SLA is advantageous only in cases when the grain yield is restricted by too short a period of preanthesis growth, as found in boreal areas. On the other hand, increase in early vigour results in rapid use of water reserves in rainfed areas early in the growing season. Ludwig \& Asseng (2010) also demonstrated that elevated $\mathrm{CO}_{2}$ reduces the benefits of SLA.

\subsection{Epigenetics and the thermosensing of flowering pathways}

Flowering, which is essential for the partitioning of biomass into grain yield, is initiated in response to both environmental cues (temperature, daylength) and the autonomous pathway that is related to the developmental stage of plant. The relative contributions of the two pathways to flowering vary among species (Amasino \& Michaels, 2010). Flowering is a major developmental pathway that is regulated by ambient temperature. The acceleration of flowering in Arabidopsis by higher temperature requires genes from the autonomous pathway (Blázquez et al., 2003), and is dependent on increasing expression of FLOWERING LOCUS T (FT) (Balasubramanian et al., 2006). This thermosensing response in Arabidopsis is due to the epigenetic regulation of chromatin structure that leads to changes in chromatin integrity (Kumar \& Wigge, 2010). Epigenetic regulation also affects vernalization, another temperature-dependent pathway of flowering. FLOWERING LOCUS C (FLC), the key gene in vernalization, is progressively repressed when plants are exposed to cold during winter. This repressed state later facilitates flowering induction in spring, and continues even when cold is not present, indicating that a long cold period confers a cellular "memory" of winter (Sung \& Amasino, 2006). The transition from vegetative to reproductive growth in plants is now understood to be strongly influenced by epigenetic control mechanisms, and the effects of stresses on these mechanisms need to be investigated in order to allow better control of the onset of flowering in a changing environment (Mittler \& Blumwald, 2010) (Figure 4).

In addition to flowering, epigenetic regulation has important roles in other developmental processes and responses to environmental cues, including abiotic and biotic stress (Jarillo et al., 2009; Bennetzen \& Zhu, 2011; Deal \& Henikoff, 2011). Warmer developmental conditions and maternal drought stress can decrease seed dormancy, allowing germination in nonoptimal conditions (Qaderi et al., 2006). Hence, high temperature can also have an impact on seed lot homogeneity and stability.

Some environmentally induced changes in plant traits are transient, mediating acclimation response, while others are heritable epigenetic modifications that provide plants a (withinand trans-generational) stress memory that may help them cope with subsequent stresses more effectively (Chinnusamy \& Chu, 2009; Bennetzen \& Zhu, 2011). Berger et al. (2009) proposed three categories of signals that operate in the establishment of a stably heritable epigenetic state. The first is a signal from the environment, the second is a responding signal in the cell that specifies the affected chromosomal location, and the third is a sustaining signal that perpetuates the chromatin change in subsequent generations.

The heritability of environmentally induced traits has special relevance in the context of climate change, as it can have a role in long-term environmental adaptation. Several studies 
tested the existence of trans-generational epigenetic inheritance of environmentally induced traits and its stability (Paszkowski \& Grossniklaus, 2011). The underlying mechanism involves altered DNA methylation and removal, as in the case of warm temperature response, and histone variants may be exchanged, but it is difficult to distinguish epigenetic marks that are inherited from those that are reset (Paszkowski \& Grossniklaus, 2011). Epigenetic changes induced by abiotic stress may have an adaptive advantage for plants, but they may also prevent the next generation from growing to its full potential by affecting timing of the developmental phases (Chinnusamy \& Chu, 2009).

Histone variants and post-translational modifications to histones are able to alter physical properties of nucleosomes and serve as a mechanism for regulating DNA exposure. Histone variant $\mathrm{H} 2 \mathrm{~A} . \mathrm{Z}$, and $\mathrm{H} 2 \mathrm{~K} 4$ and $\mathrm{H} 3 \mathrm{~K} 27$ methylation, are key elements in the regulation of genes involved in developmental processes of plants, including the vegetative to reproductive transition (regulation of $F L C$ ) and in stress responses (Deal \& Henikoff, 2011). Histone variant H2A.Z is unstable in warm temperatures, and its nucleosome occupancy declines, so it is suggested to act as temperature sensor (Kumar \& Wigge, 2010). The chromatin status at the FT locus responds to temperature and is altered in the absence of H2A.Z (Kumar \& Wigge, 2010), allowing the expression of FT in response to higher temperature (independently of CONSTANS, CO).

Understanding the molecular basis of the temperature sensing mechanism is essential in order to predict the responses of plants to further increases in temperature and to use this information in breeding crops to cope with climate change. The rate of development is largely determined by responses to temperature and photoperiod, and it is possible to quantify and predict the effects both of temperature and of photoperiod at optimum and suboptimum temperatures (Craufurd \& Wheeler, 2007). However the mechanism of action of the effects of temperature and photoperiod on developmental stages above the optimum temperature are not well understood (Craufurd \& Wheeler, 2007).

In general, the phenological stages determining yield of autumn-sown crops occur earlier than in spring-sown crops, thereby avoiding heat stress, but also being slower and allowing a longer period for tiller and spikelet formation. An early beginning of the growing season and low spring temperatures increase tiller formation, whereas increasing temperatures between stem elongation and anthesis decrease the number of tillers. A slight increase in winter temperatures would increase the yield of winter cereals at high latitudes, since it would result in more head-bearing tillers and more grains per head (Chmielewski \& Köhn, 2000). Winter crops have better access to water reserves in early spring and are thus less sensitive to drought (Chmielewski \& Köhn, 2000). Tiller survival is, however, very sensitive to water deficit, which can have a marked role in some years. The crop canopy is leafy in early spring before the spring crops are sown and thus, the canopy can make better use of incoming radiation (Figure 5). Many of the same principles apply to autumn-sown broadleaf crops with an indeterminate growth habit, such as faba bean (Link et al., 2010) and turnip rape (Mäkelä et al., 2011).

Warmer soil temperature increased the green leaf area index, above-ground biomass, and nitrogen content during early developmental stages of winter wheat, without significantly affecting the generative stages and yield of the crop (Patil et al., 2010). Thus the crop had an opportunity to utilize the incoming radiation for accumulating biomass and nitrogen, which could at later stage be converted into grain yield.

Modelling of sorghum (Sorghum bicolor L.), a C4 plant, showed that in the presence of drought, increased rooting depth maintained or increased yield in spite of drought-reduced 
RUE, and also reduced yield variability (Sinclair \& Muchow, 2001). Utilization of carbohydrate reserves stored in the stem allows continuation of grain filling in drought- or heat-stressed cereal plants (Blum, 2005). Reduced plant size and leaf area mainly account for increased water use efficiency in crops, but they usually result in lower yield potential. Hence Blum (2009) developed the concept of "effective use of water", whereby emphasis is returned to maximized yield rather than to limited water use. Component traits included large leaf area with selective killing of older leaves under stress, and osmotic adjustment that allows fast recovery after stress relief (Blum, 2005, 2009). Temporary storage of carbohydrate reserves, as found in many cereal stems, allows a crop to adjust to fluctuation of assimilate supply by maintaining a viable sink, preventing sink-limitation and feedback inhibition of the enhanced potential photosynthesis following elevated $\mathrm{CO}_{2}$ levels.

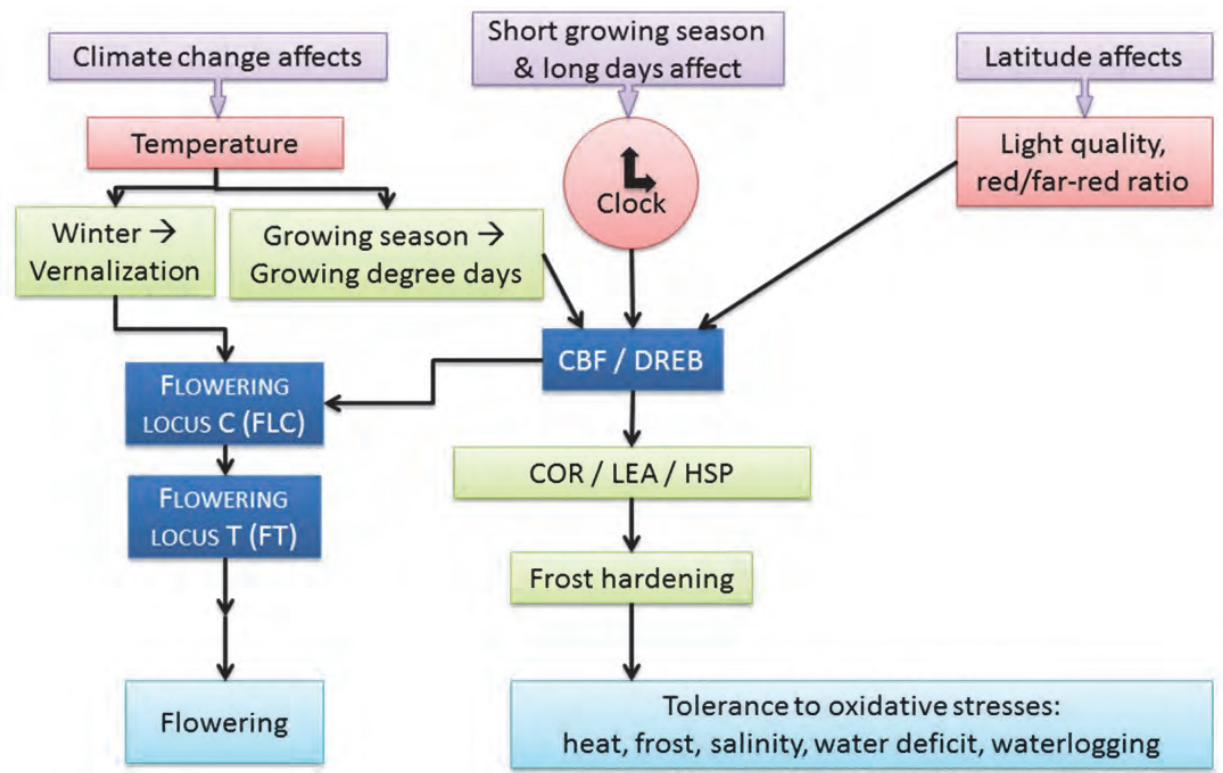

Fig. 4. Pathways affecting flowering and stress responses as influenced by climate change in the boreal region. CBF/ DREBs (C-REPEAT BINDING FACTOR/DEHYDRATIONRESPONSIVE ELEMENT BINDING FACTOR) have a central role in cold acclimation and responses to abiotic stresses and are regulated by temperature and light. CBF activates COLD-RESPONSIVE/LATE EMBRYOGENESIS-ABUNDANT (COR/LEA) genes that improve freezing, drought and salinity tolerance. Heat stress induces DREB2A that improves heat tolerance through the HEAT SHOCK TRANSCRIPTION FACTOR-HEAT SHOCK PROTEIN (HSF-HSP) pathway. Vernalization and CBF act in a coordinated fashion to regulate FLC that, in turn, regulates further downstream genes to induce flowering. (Adapted from Chew \& Halliday, 2011)

\section{Challenges and limitations for crop improvement}

Abiotic stress is a primary cause of crop loss, reducing average yields of most crop plants by more than 50\% (Boyer, 1982; Bray et al., 2000). In the future, increased episodes of abiotic 
stresses can lead to even more severe losses in yield. The production of crops with improved responses to wide-ranging environmental conditions is needed, for boreal agriculture as much as for that at lower latitudes. Adaptation options that may be explored to minimize negative impacts of climate change and to take advantage of positive impacts include changes in crop species, cultivar, sowing date, fertilization, irrigation, drainage, land allocation and farming system (Olesen \& Bindi, 2002).

Breeding methodology should, as always, be effective. Increasing yield stability under different stress conditions is a challenge to breeders as it is difficult to synchronize the crop cycle with the most favourable environmental conditions. In boreal climates, crop plants have to be adapted to both the long photoperiod and low temperature, and the combination of timing, duration, intensity, and frequency of heat, drought, frost, flooding, disease and pest stresses cannot be predicted. The full suite of technologies, including traditional breeding, mutation breeding, marker-assisted selection, genomic selection, and cis- and trans-genic technologies, will be needed to improve crop performance and yield (Jung \& Müller, 2009; Mittler \& Blumwald, 2010; Varshney et al., 2011).

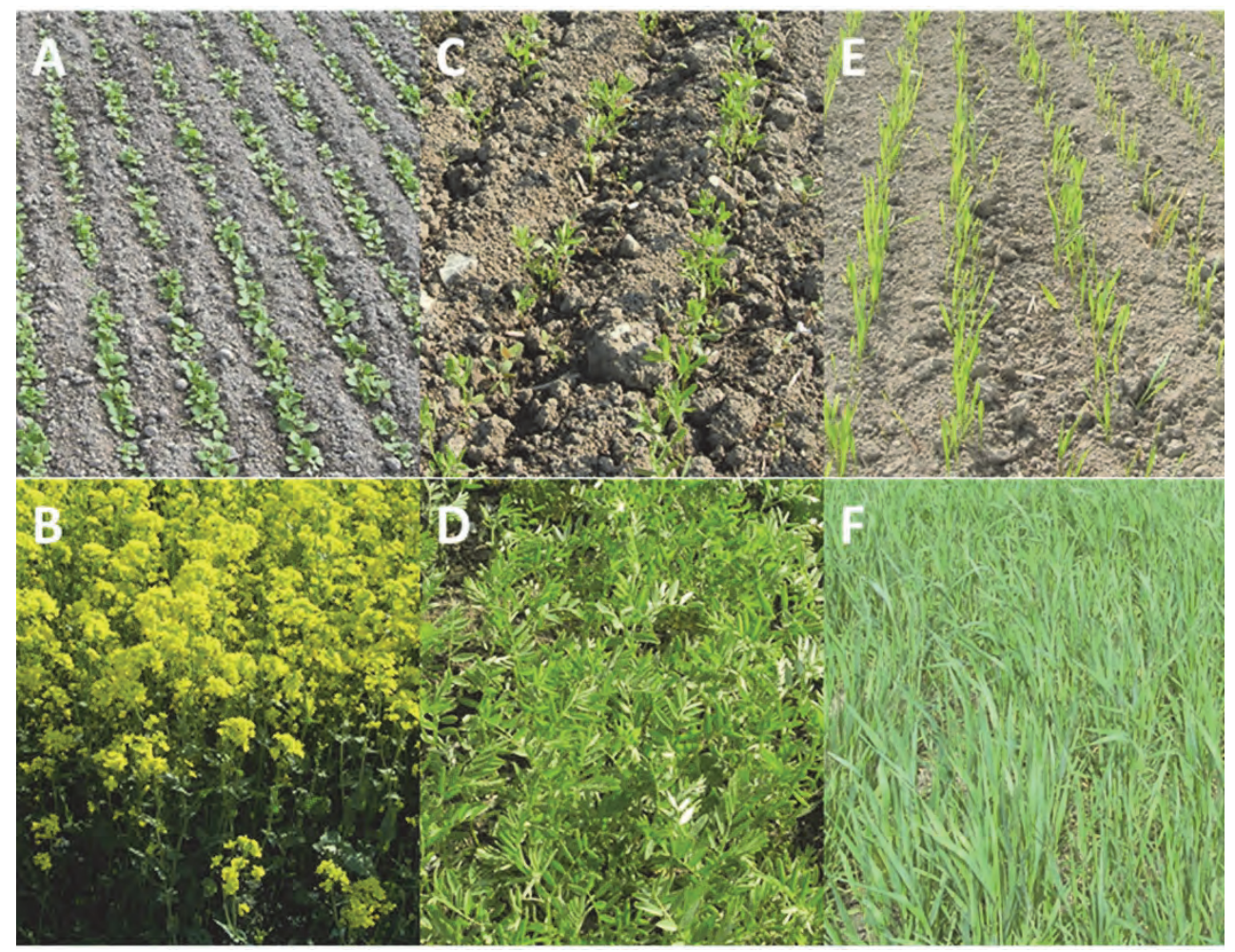

Fig. 5. Winter crops already cover the soil surface and efficiently utilize available resources, such as solar energy, when spring crops have just formed their first true leaves. A, spring turnip rape, B, winter turnip rape, C, spring lentil, D, winter lentil, E, spring cereal and F, winter cereal. All photographs were taken on 30 May 2011 (Antti Tuulos). 


\subsection{Biotechnology}

Biotechnological manipulations can assist the development of sustainable crops for the boreal zone. The availability of the complete Arabidopsis genome sequence and the increasing number of complete genomic sequences and omics tools from crop plants (Langridge \& Fleury, 2011) will reveal new candidate genes for future crop improvement and novel products. Advances in sequencing technologies have led to a rapid increase in the number of crop species for which the genome sequence is either complete or nearly so (GenBank, 2011). Together with advanced bioinformatics tools available, the integration of genome and functional omics data (transcriptomics, proteomics, metabolomics) with genetic and phenotypic information is leading to the identification and characterization of genes and pathways responsible for agronomically important phenotypes (Mittler \& Blumwald, 2010; Tester \& Langridge, 2010; Mochida \& Shinozaki, 2010; Langridge \& Fleury, 2011). Omics analyses, in which the expression of thousands of genes, changes in protein composition and metabolite profile are simultaneously examined, are crucial for understanding the whole processes of molecular networks in response to stresses, in order to improve crop resistance and productivity. Omics analyses of regulatory networks have cast light on plant abiotic stress responses (Urano et al., 2010). A relatively new omics technology is automated phenotyping or phenomics, which has progressed to the stage where even such large plants as maize can be automatically scanned, as long as they have been grown in containers in controlled conditions (www.lemnatec.com). For field-grown materials, the technology of precision agriculture, in which near infrared (NIR) scanners are placed in combine harvesters, has been adapted and tractor-mounted NIR scanners read the spectra from growing crops (Montes et al., 2007).

Genes of potential importance can be transferred into elite germplasm, through molecular breeding in the same species, or across species by using genetic engineering. When the naturally occurring variation is not enough, genetic engineering permits the generation of novel variation and traits. The potential of using genetic engineering for crop improvement in modern agriculture facing climate change has recently been reviewed by Mittler \& Blumwald (2010).

Engaging multiple stress pathways by manipulating the expression of specific transcription factors has proven to be a useful approach for improving abiotic stress tolerance (Century et al., 2008; Yang et al., 2010; Long \& Ort, 2010; Chew \& Halliday, 2011). C-repeat binding factor (CBF) and abscisic acid-responsive element (ABRE) transcription factors (TF) confer tolerance to multiple abiotic stresses, including cold, drought, heat and oxidative stress (Hua 2009; Thomashow, 2010; Chew \& Halliday, 2011; Dong et al., 2011). As these regulatory pathways are conserved among species, and are present in hardy crops as well in species that are chilling sensitive, it is possible to modify pathways in one plant using TF from another plant (Jaglo et al., 2001; Nakashima et al., 2006). Targeted genetic engineering using CBF/ABREs can result in improved survival rates in crops and also gives a chance to increase the number of crop species for cultivation (Figure 4).

\subsection{Flowering}

The synchrony of the life cycle of a plant to the changing seasons is particularly important in boreal environments where extreme changes in environmental conditions occur at different times of the year. Timing developmental events to coincide with favourable seasonal conditions is critical for plant growth, survival and reproduction, and in crop plants this means harvestable yield. Temperate plants respond to and often use the combination of 
daylength, vernalization and temperature to ensure optimal timing of flowering. The appropriate timing of flowering is pivotal for reproductive success in plants, and hence the transition to flowering is controlled both by endogenous developmental factors and environmental cues (Amasino \& Michaels, 2010). This aspect of adaptation already limits the use of imported cultivars in the boreal zone and in the projected future climate, novel combinations of environmental and seasonal cues can have an effect on the flowering-time gene network with important consequences for plant life history.

The molecular biology of seasonal flowering responses has been elucidated in Arabidopsis (Amasino \& Michaels, 2010), and in cereals the components involved in flowering and vernalization are well characterized (Alexandre \& Hennig, 2008; Greenup et al., 2009; Kim et al., 2009). The basic photoperiod pathway appears to be conserved in flowering plants, converging on the activation of FT (Mouradov et al., 2002). FT encodes florigen, a small protein that is a strong promoter of flowering (Turck et al., 2008). In Arabidopsis, FLC represses expression of $F T$ until this repression is removed through the silencing of $F L C$ by vernalization, the process by which prolonged exposure to cold makes plants competent to flower (Kim et al., 2009). In cereals, VERNALIZATION 2 (VRN2) acts as a flowering repressor that, like $F L C$, is turned off during cold exposure (Galiba et al., 2009; Greenup et al., 2009). Although the proteins coded by VRN2 and FLC are not homologues, the functional role for repressors is the same, namely the repression of FT (called VRN3 in cereals). Pin et al. (2010) demonstrated another strategy to regulate vernalization in sugar beet, a biennial crop, where the regulation of flowering time is controlled by the interplay of two paralogs of the FT gene, BvFT1 and BvFT2, that have antagonistic functions. BvFT2 is functionally conserved with FT and essential for flowering, whereas BvFT1 represses flowering and its down-regulation is crucial for the vernalization response in beet.

The molecular biology of flowering is presently being intensively investigated in order to identify genes involved and their interactions in crop plants. The genetic basis of flowering is important for plant breeding and improvement strategies, as well as for predicting and managing responses to changing climates. The timing of flowering is important for adaptation to and avoidance of abiotic stresses. In many annual crops, brief episodes of hot temperatures $\left(>32-36^{\circ} \mathrm{C}\right)$ or a single night frost are well known to cause severe damage at flowering, and as a consequence reduce crop yield. Faba bean ovules, for example, are susceptible to a fraction of a degree of frost (Link et al., 2010).

Delaying time of flowering can be used to optimize biomass production where the whole plant is used. Late-flowering cultivars of maize are chosen for boreal conditions in order to optimize whole-crop biomass and quality for forage or bioenergy use (Pakarinen et al., 2011). Similarly, transforming tobacco with an Arabidopsis FLC construct that delayed flowering resulted in a significant increase in dry matter production (Salehi et al., 2005).

Targeting genetic manipulation to increase freezing tolerance by using CBFs and/or genes involved in timing of flowering will produce crop varieties that are able to withstand or avoid sub-optimal growing conditions. Elegant work on poplar (Populus tremula L.) (Böhlenius et al., 2006) and sugar beet (Pin et al., 2010) shows that combining the information obtained from Arabidopsis with profound knowledge about flowering physiology can produce outcomes with high value in crop breeding. PtFT1 (FT ortholog) controls both flowering and the growth cessation and bud set in the fall, indicating that FT orthologs have a more general role in regulating biological processes subjected to photoperiod than previously anticipated (Böhlenius et al., 2006). The increased knowledge about "critical daylength" is central for our ability to adapt plants to new climates. In 
addition, with the ability to manipulate FT activity, it is possible to either prolong or shorten the growing season of plant and to accelerate the breeding process (Böhlenius et al., 2006).

European attitudes and regulatory policies concerning GMOs are highly negative and restrictive. Creation of marker-free plants (antibiotic-free constructs) and the use of cis-genic vectors (www.cisgenics.com), in which only host gene sequences are used, go partway toward answering the criticism and may make it easier to licence GM crops.

\section{Conclusion: building a resilient boreal agriculture}

Warmer conditions will reduce some limitations to crop production in high latitudes. Taking full advantage of these opportunities, without losing too much to the countervailing stresses, will require new interdisciplinary interactions between soil scientists, microbiologists and crop scientists (including agronomists, breeders and pathologists). We propose that a resilient boreal agriculture can be built on three pillars: diversity, sustainability and technology.

\subsection{Diversity}

Crop diversity has many well known advantages, several of which have been undervalued by the Common Agricultural Policy of recent decades. First among these is that rotational diversity breaks a number of cycles, particularly soil-borne disease cycles of the primary crops, usually small-grain cereals. The weed, pathogen and pest fauna and flora of different crops are different, so the control measures differ, and rotation reduces the prospects that these populations develop resistance to the control measures. At the countryside scale, a patchwork of different crop species and cultivars can help slow the spread of diseases or reduce their impact on farm income. The different root morphologies of different crops lead to exploration of different soil layers and usage of a different balance of nutrients, and leave residues of different types, thus helping to maintain the structure and biological diversity of soil. Break crop effects have been quantified in a number of systems, with the benefits to the following wheat crop reaching $60 \%$ in some experiments in Saskatchewan and Sweden (Kirkegaard et al., 2008).

Crop diversity offers other opportunities. Fibre hemp (Cannabis sativa L.) can be used for industrial fibre or bioenergy, and provides reliable yields at high latitudes (Pakarinen et al., 2011). Flax (Linum usitatissimum L.) fibre commands premium prices in the fabric market, and the seed residue is valuable as a functional food. Microbiological diversity can be more productively exploited. In addition to appropriate rhizobium inoculants for legumes, inoculants of mycorrhizal fungi and plant growth-promoting bacteria are already on the market, although their value has yet to be demonstrated in many circumstances.

\subsection{Sustainability}

In the context of increasing knowledge about the releases of greenhouse gases from soil, leaching of nutrients from arable and livestock farms, and pollution of inland waterways, inputs to agriculture should clearly be managed in an appropriate fashion. This does not mean low-input or organic management, but an "ecological intensification" (a concept that has evolved in several directions since adopted by Cassman, 1999). Integrated management is a central part of this paradigm. Catch and cover crops take up nutrients in the autumn and hold them in tissues while their roots hold soil particles into the spring, thereby reducing both leaching and erosion. Grasses such as ryegrass, legumes such as clovers, and other crops including winter turnip rape, all have potential for use in this way. 
Crop diversity contributes to sustainability. Legumes have several roles, including $\mathrm{N}$ fixation, support of $\mathrm{H}$-fixing soil bacteria, release of bound soil phosphorus, and the supply of pollen and nectar to bees. Mixed clover-grass pastures require little or no $\mathrm{N}$ fertilizer, in contrast to the $300 \mathrm{~kg} /$ ha of $\mathrm{N}$ fertilizer that is applied to many grass pastures. Stockfeed can be produced from legume crops near the point of use, replacing soybean or other meal imported from overseas. Novel foods can also be produced from legume crops, and regionally novel legumes have been successfully introduced into boreal or nemoral agriculture, including blue lupin (Lupinus angustifolius L.) and lentil (Lens culinaris Medik.).

Oilseed brassicas are well adapted to boreal agriculture and make important contributions to sustainability that could be further enhanced, such as their potential for biofumigation of soil-borne pathogens and pests (Matthiessen \& Kirkegaard, 2006). Similarly, hemp not only suppresses weeds through its ground-covering ability, shown in our experiments, but also is reputed to have allelopathic effects (Singh \& Thapar, 2003).

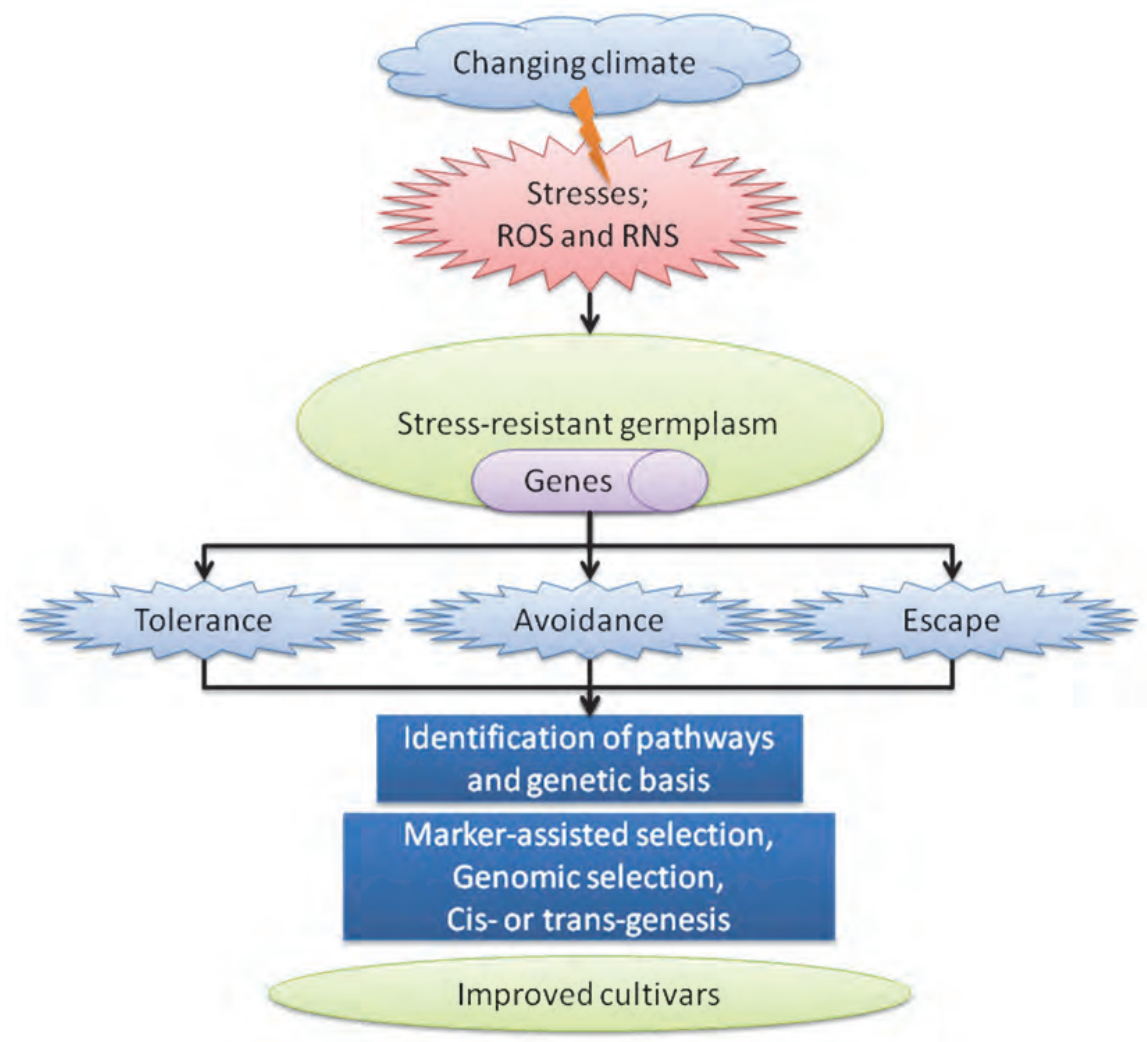

Fig. 6. Breeding of crops for the changed boreal climate requires information at different levels. Germplasm collections contain stress-resistant accessions, and the resistance may take the form of tolerance, avoidance or escape. The genetic basis of the resistance often needs to be elucidated. Modern, precise breeding technologies can then be used to produce cultivars with superior response to stressing environments. 


\subsection{Technology}

Crop breeding has been greatly accelerated by the development and application of a range of technologies including doubled haploidy for rapid homozygosity, marker-assisted selection, genetic transformation, and comparative omics (Figure 6). Some of these technologies are expensive to implement and others are based on information such as complete gene sequences that are expensive to derive. These expenses can be prohibitive when boreal cropping is at the fringes of agriculture, with particular requirements regarding daylength and season length, and when some of the key crops, like turnip rape, are not globally important. International cooperation is necessary to ensure that progress on the regionally important crops, in the regional conditions, is made sufficiently rapidly that the region is able to capitalize on the changing climate. The development of hardier winter crops, with better tolerance to snow cover and resistance to snow mould, is a high priority. Energy conversion technologies have a role in future boreal agriculture and will affect sustainability as well. Manure is often unproductively managed in boreal systems, but it contains both energy and valuable nutrients. Spreading of manure allows unproductive leaching of nutrients and release of methane to the atmosphere, whereas treating it in a methane digester captures the methane and some of the energy, while producing a nutrientrich digestate that can be used as a fertilizer. Supplementing the methane digester with plant material allows capture of some of the energy from the cellulose while the lignin remains in the solid residue, potentially adding to soil carbon stocks. A high-biomass legume crop, such as annual white lupin (Lupinus albus L.) or perennial fodder galega (Galega orientalis Lam.) that can produce $14 \mathrm{t} /$ ha of dry matter, can fix far more nitrogen than can be used for the following crop. By passing such a crop through a methane digester, energy can be gained, and enough nitrogen fertilizer for 3-5 times the original field area can be obtained.

Agriculture must be transformed. The rapid advances in technologies, including precision agriculture and omics sciences, can help bring the diversity required to add sustainability to boreal agricultural production in time to meet the challenges of climate change.

\section{References}

Aksouh, N.M., Jacobs, B.C., Stoddard, F.L. \& Mailer, R. 2001. Response of canola to different heat stresses. Australian Journal of Agricultural Research 52, 817-824, ISSN 0004-9409

Alonso, A., Pérez, P., Morcuende, R. \& Martinez-Carrasco, R. (2008). Future $\mathrm{CO}_{2}$ concentrations, though not warmer temperatures, enhance wheat photosynthesis temperature responses. Physiologia Plantarum, 132, 102-112, ISSN 0031-9317

Alexandre, C. M. \& Hennig, L. (2008). FLC or not FLC: the other side of vernalization. Journal of Experimental Botany, 59, 1122-1135, ISSN 0022-0957

Amasino, R. M. \& Michaels, S. D. (2010). The timing of flowering. Plant Physiology, 154, 516520, ISSN 0032-0889

Avola, B., Cavallaro, V., Patanè, C. \& Riggi, E. (2008). Gas exchange and photosynthetic water use efficiency in response to light, $\mathrm{CO}_{2}$ concentration and temperature in Vicia faba. Journal of Plant Physiology, 165, 796-804, ISSN 0176-1617

Balasubramanian, S., Sureshkumar, S., Lempe, J. \& Weigel, D. (2006). Potent induction of Arabidopsis thaliana flowering by elevated growth temperature. PLoS Genetics, 2, e106, ISSN 1553-7390 
Bennetzen, J. L. \& Zhu, J.-K. (2011). Epigenetics of the epigenome. Current Opinion in Biology, 14, 113-115, ISSN 1369-5266

Berger, S. L., Kouzarides, T., Shiekhattar, R. \& Shilatifard, A. (2009). An operational definition of epigenetics. Genes $\mathcal{E}$ Development, 23, 781-783, ISSN 0890-9369

Bertrand, A., Castonguay, Y., Nadeau, P., Laberge, S., Michaud, R., Belanger, G. \& Rochette, P. (2003). Oxygen deficiency affects carbohydrate reserves in overwintering forage crops. Journal of Experimental Botany, 54, 1721-1730, ISSN 0022-0957

Blázquez, M. A., Ahn, J. H. \& Weigel, D. (2003). A thermosensory pathway controlling flowering time in Arabidopsis thaliana. Nature Genetics, 33, 168-171, ISSN 1061-4036

Blokhina, O. \& Fagerstedt, K. (2010). Oxidative metabolism, ROS and NO under oxygen deprivation. Plant Physiology and Biochemistry, 48, 359-373, ISSN 0981-9428

Bloom, A. J., Burger, M., Asensio, J. S. R. \& Cousins, A. B. (2010). Carbon dioxide enrichment inhibits nitrate assimilation in wheat and Arabidopsis. Science, 328, 899-903, ISSN 0036-8075

Blum, A. (2005). Drought resistance, water-use efficiency, and yield potential - are they compatible, dissonant, or mutually exclusive? Australian Journal of Agricultural Research, 56, 1159-1168, ISSN 0004-9409

Blum, A. (2009). Effective use of water (EUW) and not water-use efficiency (WUE) is the target of crop yield improvement under drought stress. Field Crops Research, 112, 119-123, ISSN 0378-4290

Boyer, J.S. (1982). Plant productivity and environment. Science , 218, 443-448, ISSN 0036-8075

Bray, E. A., Bailey-Serres, J. \& Weretilnyk, E. (2000). Responses to abiotic stresses. In: Biochemistry and Molecular Biology of Plants. Buchanan B, Gruissem W, Jones R pp. 1158-1249, American Society of Plant Physiologist, ISBN 0-943088-39-9, Rockville, MD, USA

Brisson, N., Gate, F., Gouache, D., Charmet, G., Oury, F.-X. \& Huard, F. (2010). Why are wheat yields stagnating in Europe? A comprehensive data analysis for France. Field Crops Research, 119, 201-212, ISSN 0378-4290

Böhlenius, H., Huang, T., Charbonnel-Campaa, L., Brunner, A. M., Jansson, S., Strauss, S. H. \& Nilsson, O. (2006). CO/FT regulatory module controls timing of flowering and seasonal growth cessation of trees. Science, 312, 1040-1043, ISSN 0036-8075

Cantarel, A. A. M., Bloor, J. M. G., Deltroy, N. \& Soussana, J.-F. (2011). Effects of climate change drivers on nitrous oxide fluxes in an upland temperate grassland. Ecosystems, 14, 223-233, ISSN 1432-9840

Carter, T. R. (1998). Changes in the thermal growing season in Nordic countries during the past century and prospects for the future. Agricultural Food Science in Finland, 7, 161-179, ISSN 1459-6067

Cassman, K. G. (1999). Ecological intensification of cereal production systems: Yield potential, soil quality, and precision agriculture. Proceedings of the National Academy of Sciences in the United State of America, 96, 5952-5959, ISSN 0027-8424

Century, K., Reuber, T. L. \& Ratcliffe, O. J. (2008). Regulating the regulators: The future prospects for transcription-factor-based agricultural biotechnology products. Plant Physiology, 147, 20-29, ISSN 0032-0889

Chew, Y. H. \& Halliday K. J. (2011). A stress-free walk from Arabidopsis to crops. Current Opinion in Biotechnology, 22, 281-286, ISSN 0958-1669 
Chinnusamy, V. \& Zhu J.-K. (2009). Epigenetic regulation of stress responses in plants. Current Opinion in Biotechnology, 12, 133-139, ISSN 0958-1669

Chmielewski, F. M. \& Köhn, W. (2000). Impact of weather on yield components of winter rye over 30 years. Agricultural and Forest Meteorology, 102, 253-261, ISSN 0168-1923

Clarke, F. R., Clarke, J. M., DePauw, R. M., Fernandez, M. R., Fox, S.,Gilbert, J., Humphreys, G., Knox, R. E., McCaig, T. N., Procunier, D., Sissons, M. \& Somers, D. (2005). Strategic approach to mitigating weather induced defects of wheat quality. Euphytica, 143, 285-290, ISSN 0014-2336

Colmer, T. D. \& Voeseneck, L. A. C. J. (2009). Flooding tolerance: Suites of plants traits in variable environments. Functional Plant Biology, 36, 665-681, ISSN 1445-4408

Craufurd, P. Q. \& Wheeler, T. R. (2009). Climate change and the flowering time of annual crops. Journal of Experimental Botany, 60, 2529-2539, ISSN 0022-0957

Deal, R. B. \& Henikoff, S. (2011). Histone variants and modifications in plant gene regulation. Current Opinion in Plant Biology, 14, 116-122, ISSN 1369-5266

Deleens, E., Marcotte, L., Schwebel-Dugue, N. \& Vartanian, N. (1989). Stable isotope carbon study: Long-term partitioning during progressive drought stress in Brassica napus var. oleifera. Plant Cell and Environment, 12, 615-620, ISSN 0140-7791

Dickin, E., Bennett, S. \& Wright, D. (2009). Growth and yield responses of UK wheat cultivars to winter waterlogging. Journal of Agricultural Science, 147, 127-140, ISSN 0021-8596

Dickin, E. \& Wright, D. (2008). The effects of winter waterlogging and summer drought on the growth and yield of winter wheat (Triticum aestivum L.). European Journal of Agronomy, 28, 234-244, ISSN 1161-0301

Duveiller, E., Singh, R. P. \& Nicol J. M. (2007). The challenges of maintaining wheat productivity: pests, diseases, and potential epidemics. Euphytica,157, 417-430, ISSN 0014-2336

Dong, M. A., Farré, E. M. \& Thomashow, M. F. (2011). CIRCADIAN-CLOCK-ASSOCIATED 1 and LATE ELONGATED HYPOCOTYL regulate expression of the C-REPEAT binding factor (CBF) pathway in Arabidopsis. Proceedings of the National Academy of Sciences in the United State of America, 108, 7241-7246, ISSN 0027-8424

Estrella, N., Sparks, T. H. \& Menzel, A. (2007). Trends and temperature response in the phenology of crops in Germany. Global Change Biology, 13, 1737-1747, ISSN 13541013

Ewert, F. \& Pleijel, H. (1999). Phenological development, leaf emergence, tillering and leaf area index, and duration of spring wheat across Europe in response to $\mathrm{CO}_{2}$ and ozone. European journal of Agronomy, 10, 171-184, ISSN 1161-0301

Fleisher, D. H., Timlin, D. J. \& Reddy, V. R. (2006). Temperature influence on potato leaf and branch distribution and on canopy photosynthetic rate. Agronomy Journal, 98, 14421452, ISSN 0002-1962

Fleisher, D. H., Timlin, D. J. \& Reddy, V. R. (2008). Elevated carbon dioxide and water stress effects on potato canopy gas exchange, water use, and productivity. Agricultural and Forest Meteorology, 148, 1109-1122, ISSN 0168-1923

Foulkes, M. J., Hawkesford, M. J., Barraclough, P. B., Holdsworth, M. J., Kerr, S., Kightley, S. \& Shewry, P. R. (2009). Identifying traits to improve the nitrogen economy of wheat: Recent advances and future prospects. Field Crop Research, 114, 329-342, ISSN 0378-4290 
Franzaring, J., Högy, P. \& Fangmeier, A. (2008). Effects of free-air $\mathrm{CO}_{2}$ enrichment on the growth of summer oilseed rape (Brassica napus cv. Campino). Agriculture, Ecosystems and Environment, 128, 127-134, ISSN 0167-8809

Fronzek, S. \& Carter, T. R. (2007). Assessing uncertainties in climate change impacts on resource potential for Europe based on projections from RCMs and GCMs. Climatic Change, 81, 357-371, ISSN 0165-0009

Galiba, G., Vágújfalvi, A., Li, C., Soltész, A. \& Dubcovsky, J. (2008). Regulatory genes involved in the determination of frost tolerance in temperate cereals. Plant Science, 176, 12-19, ISSN 0168-9452

GenBank 2011. http:/ / www.ncbi.nlm.nih.gov/genomes/ Visited 31 May 2011.

Greenup, A., Peacock, W. J., Dennis, E. S. \& Trevaskis, B. (2009). The molecular biology of seasonal flowering-responses in Arabidopsis and in cereals. Annals of Botany, 103, 1165-1172, ISSN 0305-7364

Groffman, P. M., Driscoll, C. T., Fahey, T. J., Hardy, J. P., Fitzhugh, R. D. \& Tierney, G. L. (2001). Colder soils in a warmer world: a snow manipulation study in a northern hardwood forest ecosystem. Biogeochemistry, 56, 135-150, ISSN 0168-2563

Harris, C., Arenson, L.U., Christiansen, H. H., Etzelmüller, B., Frauenfelder, R., Gruber, S.; Haeberli, F., Hauck, C., Hölzle, M., Humlum, O., Isaksen, K., Kääb, A., KernLütschg, M. A., Lehning, M., Matsuoka, M., Murton, J. B., Nötzli, J., Phillips, M., Ross, N., Seppälä, M., Springman, S. M. \& Vonder Mühll, D. (2009). Permafrost and climate in Europe: Monitoring and modelling thermal, geomorphological and geotechnical responses. Earth Science Reviews, 92, 117-171, ISSN 0012-8252

Haverkort, A. J. \& Verhagen, A. (2008). Climate change and its repercussions for the potato supply chain. Potato Research, 51, 223-237, ISSN 0014-3065

Heide, O. M. (1988). Flowering requirements of Scandinavian Festuca pratensis. Physiologia Plantarum, 74, 487-492, ISSN 0031-9317

Henry, H. A. (2008). Climate change and soil freezing dynamics: historical trends and projected changes. Climatic Change, 87, 421-434, ISSN 0165-0009

Hirel, B., Le Gouis, J., Ney, B. \& Gallais, A. (2007). The challenge of improving nitrogen use efficiency in crop plants towards a more central role for genetic variability and quantitative genetics within integrated approaches. Journal of Experimental Botany, 58, 2369-2387, ISSN 0022-0957

Hömmö, L. M. (1994). Hardening of some winter wheat (Triticum aestivum L.), rye (Secale cereale L.), triticale ( $\times$ Triticosecale Wittmack) and winter barley (Hordeum vulgare L.) cultivars during autumn and the final winter survival in Finland. Plant Breeding, 112, 285-293, ISSN 0179-9541

Hua, J. (2009). From freezing to scorching, transcriptional responses to temperature variations in plants. Current Opinion in Plant Biology, 12, 568-573, ISSN 1369-5266

Intergovernmental Panel on Climate Change (IPCC). (2007) Fourth Assessment Report: Climate Change 2007. Cambridge University Press, Cambridge, UK ., ISBN 9780 521705974

Jaglo, K. R., Kleff, S., Amundsen, K. L., Zhang, X., Haake, V., Zhang, J. Z., Deits, T. \& Thomashow, M. F. (2001). Components of the Arabidopsis C-repeat/dehydration reasponsive element binding factor cold-response pathway are conserved in Brassica napus and other plant species. Plant Physiology, 127,910-917, ISSN 0032-0889 
Jamalainen, E. A. (1974). Resistance in winter cereals and grasses to low-temperature parasitic fungi. Annual Review in Phytopathology, 12, 281-302, ISSN 0066-4286

Jamalainen, E. A. (1978). Peltokasvien talvehtiminen Suomessa. Wintering of field crops in Finland. Journal of the Scientific Agricultural Society of Finland, 50, 468-519, ISSN 14596067

Jarillo, J. A., Píneiro, M., Cubas, P. \& Martinez-Zapater, J. M. (2009). Chromatin remodeling in plant development. International Journal of Developmental Biology, 53, 1581-1596, ISSN 0214-6282

Jung, C. \& Müller, A. E. (2009). Flowering time control and applications in plant breeding. Trends in Plant Science, 14, 563-573, ISSN 1360-1385

Kim, D. H., Doyle, M. R., Sung, S. \& Amasino, R. M. (2009). Vernalization: winter and the timing of flowering in plants. Annual Review of Cell Developmental Biology, 25, 277299, ISSN 1081-0706

Kirkegaard, J., Christen, O., Krupinsky, J. \& Layzell, D. (2008). Break crop benefits in temperate wheat production. Field Crops Research, 107, 185-195, ISSN 0378-4290

Kreyling, J. (2010). Winter climate change: a critical factor for temperate vegetation performance. Ecology, 91,1939-1948, ISSN 0012-9658

Kreyling, J., Beierkuhnlein, C., Pritsch, K., Schloter, M. \& Jentsch, A. (2007). Recurrent soil freeze-thaw cycles enhance grassland productivity. New Phytologist, 177, 938-945, ISSN 0028-646X

Kumar, S. V. \& Wigge, P. A. (2010). H2A.Z-containing nucleosomes mediate the thermosensory response in Arabidopsis. Cell, 140, 136-147, ISSN 0092-8674

Langridge, P. \& Fleury, D. (2011). Making the most of 'omics' for crop breeding. Trends in Biotechnology, 29, 33-40, ISSN 0167-7799

Lawson, T., Craigon, J., Black, C. R., Colls, J. J., Landon, G. \& Weyers, D. B. (2002). Impact of elevated $\mathrm{CO}_{2}$ and $\mathrm{O}_{3}$ on gas exchange parameters and epidermal characteristics in potato (Solanum tuberosum L.). Journal of Experimental Botany, 53, 737-746, ISSN 0022-0957

Leakey, A. D. B., Ainsworth, E. A., Bernacchi, C. J., Rogers, A., Long, S.P . \& Ort D. R. (2009). Elevated $\mathrm{CO}_{2}$ effects on plant carbon, nitrogen, and water relations: six important lessons from FACE. Journal of Experimental Botany, 60, 2859-2876, ISSN 0022-0957

Link, W., Balko, C. \& Stoddard, F. L. (2010). Winter hardiness in faba bean: Physiology and breeding. Field Crops Research, 115, 287-296, ISSN 0378-4290

Long, S. P. \& Ort, D. R. (2010). More than taking the heat: crops and global change. Current Opinion in Plant Biology, 13, 241-248, ISSN 1369-5266

Luck, J., Spackman, M., Freeman, A., Trebicki, A., Griffiths, P., Finlay, K. \& Chakraborty, S. (2011). Climate change and diseases of food crops. Plant Pathology, 60, 113-121, ISSN 0032-0862

Ludwig, F. \& Asseng, S. (2010). Potential benefits of early vigor and changes in phenology in wheat to adapt to warmer and drier climates. Agricultural Systems, 103, 127-136, ISSN 0308-521X

Luxmoore, R. J., Fischer, R. A. \& Stolzy, L. H. (1973). Flooding and soil temperature effects on wheat during grain filling. Agronomy Journal, 65, 361-364, ISSN 0002-1962

Mäkelä, P., Kleemola, J., Jokinen, K., Mantila, J., Pehu, E. \& Peltonen-Sainio, P. (1999a). Growth response of pea and summer turnip rape to foliar application of 
glycinebetaine. Acta Agriculturae Scandinavica, Section B, Soil and Plant Science, 47, 168-175, ISSN 0906-4710

Mäkelä, P., Kontturi, M., Pehu, E. \& Somersalo, S. (1999b). Photosynthetic response of drought- and salt-stressed tomato and turnip rape plants to foliar-applied glycinebetaine. Physiologia Plantarum, 105, 45-50, ISSN 0031-9317

Mäkelä, P. S. A., Tuulos, A., Turakainen, M., Santanen, A. \& Stoddard, F. L. (2011). Revitalizing the winter turnip rape crop. Acta Agriculturae Scandinavica, Section B, Soil and Plant Science 61, 195-201, ISSN 0906-4710

Matthiessen, J. N. \& Kirkegaard, J. A. (2006). Biofumigation and enhanced biodegradation: Opportunity and challenge in soilborne pest and disease management. Critical Reviews in Plant Sciences, 25, 235-265, ISSN 0735-2689

Matzner, E. \& Borken, W. (2008). Do freeze-thaw events enhance C and N losses from soils of different ecosystems? A review. European Journal of Soil Science, 59, 274-284, ISSN 1351-0754

Menzel, A., Sparks, T. H., Estrella, N., Koch, E., Aasa, A., Ahas, R., Alm-Kübler, K., Bissoll, P., Braslavska, O., Briede, A., Chmielewski, F. M., Crepinsek, Z.; Curnell, Y., Slögdahl, Å., Defila, C., Donnelly, A., Filella, Y., Jatzak, K., Mage, F., Mestre, A., Nordli, Ǿ., Penzuelas, J., Pirinen, P., Remisova, V., Scheifinger, H., Striz, M., Susnik, A., van Vliet, A. J. H., Wiegolaski, F.-E., Zach, S. \& Zust, A. (2006). European phenological response to climate change matches the warming pattern. Global Change Biology, 12, 1969-1976, ISSN 1354-1013

Mittler, R. \& Blumwald, E. (2010). Genetic engineering for modern agriculture: Challenges and perspectives. Annual Review of Plant Biology, 61, 443-462, ISSN 1543-5008

Montes, J.M., Melchinger, A.E. \& Reif, J.C. (2007). Novel throughput phenotyping platforms in plant genetic studies. Trends in Plant Science, 12,433-436, ISSN 1360-1385

Monti, A., Barbanti, L. \& Venturi, G. (2007). Photosynthesis on individual leaves of sugar beet (Beta vulgaris) during the ontogeny at variable water regimes. Annals of Applied Biology, 151, 155-165, ISSN 0003-4746

Mochida, K.. \& Shinozaki, K. (2010). Genomics and bioinformatics resources for crop improvement. Plant and Cell Physiology, 51, 497-523, ISSN 0032-0781

Mouradov, A., Cremer, F. \& Coupland, G. (2002). Control of flowering time: Interacting pathways as a basis for diversity. The Plant Cell, S111-S130, Supplement 2002, ISSN 1040-4651

Nakashima, K. \& Yamaguchi-Shinozaki, K. (2006). Regulons involved in osmotic stressresponsive and cold stress-responsive gene expression of plants. Physiologia Plantarum, 126, 62-71, ISSN 0031-9317

Olesen, J. E. \& Bindi, M. (2002). Consequences of climate change for European agricultural productivity, land use and policy. European Journal of Agronomy, 16, 239-262, ISSN 1161-0301

Olesen, J. E., Carter, T. R., Diaz-Ambrona, C. H., Fronzek, S., Heidmann, T., Hickler, T., Holt, T., Minguez, M. I., Morales, P., Palutikof, J. P., Quemada, M., Ruiz-Ramos, M., Rubaek, G. H., Sau, F., Smith, B. \& Sykes, M. T. (2007). Uncertainties in projected impacts of climate change on European agriculture and terrestrial ecosystems based on scenarios from regional climate models. Climatic Change, 81, 123-143, ISSN 0165-0009 
Pakarinen, A., Maijala, P., Stoddard, F. L., Santanen, A., Kymäläinen, M. \& Viikari, L. (2011). Evaluation of annual bioenergy crops in the Boreal zone for biogas and ethanol production. Biomass \& Bioenergy, in press, ISSN 0961-9534

Parmesan, C. \& Yohe, G. (2003). A globally coherent fingerprint of climate change impacts across natural systems. Nature, 421, 37-42, ISSN 0028-0836

Paszkowski, J. \& Grossniklaus, U. (2011). Selected aspects of transgenerational epigenetic inheritance and resetting in plants. Current Opinion in Biology, 14, 195-203, ISSN 1369-5266

Patil, R. H., Leagdsmand, M., Olesen, J. E. \& Porter, J. R. (2010). Growth and yield response of winter wheat to soil warming and rainfall patterns. Journal of Agricultural Science, 148, 553-566, ISSN 0021-8596

Philippot, L., Hallin, S. \& Schloter, M. (2007). Ecology of denitrifying prokayrotes in agricultural soil. Advances in Agronomy, 96, 249-305, ISSN 0065-2113

Pin, P. A., Benlloch, R., Bonnet, D., Wremerth-Weich, E., Kraft, T., Gielen, J. J. L. \& Nilsson, O. (2010). An antagonistic pair of FT homologs mediates the control of flowering time in sugar beet. Science, 330, 1397-1400, ISSN 0036-8075

Porter, J. R. \& Gawith, M. (1999). Temperatures and the growth and development of wheat. A review. European Journal of Agronomy, 10, 23-36, ISSN 1161-0301

Porter, J. R. \& Semenov, M. A. (2005). Crop responses to climatic variation. Philosophical Transactions of the Royal Society. B. Biological Sciences, 360, 2021-2035, ISSN 0962-8436

Prasad, P. V. V., Pisipati, S. R., Ristic, Z., Bukovnik, U. \& Fritz, A. K. (2008). Impact of nighttime temperature on physiology and growth of spring wheat. Crop Science, 48, 2372-2380, ISSN 0011-183X

Qaderi, M. M., Kurepin, L. V. \& Reid, D. M. (2006). Growth and physiological responses of canola (Brassica napus) to three components of global climate change: temperature, carbon dioxide and drought. Physiologia Plantarum, 128, 710-721, ISSN 0031-9317

Qaderi, M. M., Basraon, N. K., Chinnappa, C. C. \& Reid, D. M. (2010). Combined effect of temperature, ultraviolet- $B$ radiation, and watering regime on growth and physiological processes in canola (Brassica napus) seedlings. International Journal of Plant Sciences 171, 466-481, ISSN 1058-5893

Robredo, A., Pérez-López, U., Lacuesta, M., Mena-Petite, A. \& Muñoz-Rueda, A. (2010). Influence of water stress on photosynthetic characteristics in barley plants under ambient and elevated $\mathrm{CO}_{2}$ concentrations. Biologia Plantarum, 54, 285-292, ISSN 0006-3134

Rogers, A., Ainsworth, E. A. \& Leakey, A. D. B. (2009). Will elevated carbon dioxide concentration amplify the benefits of nitrogen fixation in legumes? Plant Physiology, 151, 1009-1016, ISSN 0032-0889

Rolland, F., Moore, B. \& Sheen, J. (2002). Sugar sensing and signalling in plants. The Plant Cell, S185-S205, Supplement 2002, ISSN 1040-4651

Rosenzweig, C., Karoly, D., Vicarelli, M., Neofotis, P., Wu, Q., Casassa, G., Menzel, A., Root, T. L., Estrella, N., Sequin, B., Tryjanowski, P., Liu, C., Rawlins, S. \& Imeson, A, (2008). Attributing physical and biological impacts to anthropogenic climate change. Nature, 453, 353-358, ISSN 0028-0836

Sairam, R. K., Kumutha, D., Ezhilmathi, K., Deshmukh, P. S. \& Srivastava, G. C. (2008). Physiology and biochemistry of waterlogging tolerance in plants. Biologia Plantarum, 52, 401-412, ISSN 0006-3134 
Salehi, H., Ransom, C. B., Oraby, H. F., Seddighi, Z. \& Sticklen, M. B. (2005). Delay in flowering and increase in biomass of transgenic tobacco expressing the Arabidopsis floral repressor gene FLOWERING LOCUS C. Journal of Plant Physiology, 162, 711-717, ISSN 0176-1617

Sinclair, T. R. \& Muchow, R. C. (1999). Radiation use efficiency. Advances in Agronomy, 65, 215-265, ISSN 0065-2113

Sinclair, T. R. \& Muchow, R. C. (2001). Systems analysis of plant traits to increase grain yield on limited water supplies. Agronomy Journal, 93, 263-270, ISSN 0002-1962

Singh, H. \& Thapar, R. (2003). Allelopathic influence of Cannabis sativa on growth and metabolism of Parthenium hysterophorus. Allelopathy Journal, 12, 61-70, ISSN 09714693

Springer, C. J. \& Ward, J. K. (2007). Flowering time and elevated atmospheric $\mathrm{CO}_{2}$. New Phytologist, 176, 243-255, ISSN 0028-646X

Stern, W. R. \& Donald, C. M. (1961). Relationship of radiation, leaf area index and crop growth-rate. Nature, 189, 597-598, ISSN 0028-0836

Sung, S. \& Amasino, R. M. (2006). Molecular genetic studies of the memory of winter. Journal of Experimental Botany, 57, 3369-3377, ISSN 0022-0957

Sun, J., Yang, L., Wang, Y. \& Ort, D. (2009). FACE-ing the global change: Opportunities for improvement in photosynthetic radiation use efficiency and crop yield. Plant Science, 177, 511-522, ISSN 0168-9452

Tester, M. \& Langridge, P. (2010). Breeding technologies to increase crop production in a changing world. Science, 327, 818-822, ISSN 0036-8075

Thomashow, M. F. (2010). Molecular basis of plant cold acclimation: Insights gained from studying the CBF cold response pathway. Plant Physiology. 154, 571-577, ISSN 00320889

Tosserams, M., Visser, A., Groen, M., Kalis, G., Magendans, E. \& Rozema, J. (2001). Combined effects of $\mathrm{CO}_{2}$ concentration and enhanced UV-B radiation on faba bean. Plant Ecology, 154, 197-201, ISSN 1385-0237

Turck, F., Fornana, F. \& Coupland, G. (2008). Regulation and Identity of Florigen: FLOWERING LOCUS T Moves Center Stage. Annual Review of Plant Biology, 59, 573-594, ISSN 1543-5008

Urano, K., Kurihara, Y., Seki, M. \& Shinozaki, K. (2010). 'Omics' analyses of regulatory networks in plant abiotic stress responses. Current Opinion in Plant Biology, 13, 132138, ISSN 1369-5266

Varshney, R. K., Bansal, K. C., Aggarwal, P. K., Datta, S.K. \& Craufurd, P. Q. (2011). Agricultural biotechnology for crop improvement in a variable climate: hope or hype? Trends in Plant Science. 16, 363-371, ISSN 1360-1385

Walther, G.-R., Post, E., Convey, P., Menzel, A., Parmesank, C., Beebee, T. J. C., Fromentin, J.-M., Hoegh-Guldberg, O. \& Bairlein, F. (2002). Ecological responses to recent climate change. Nature, 416, 389-395, ISSN 0028-0836

Weih, M. \& Karlsson, P. S. (2002). Low winter soil temperature affects summertime nutrient uptake capacity and growth rate of mountain birch seedlings in the subarctic, Swedish Lapland. Arctic, Antarctic, and Alpine Research, 34, 434-439, ISSN 1523-0430

$\mathrm{Wu}, \mathrm{D}$. \& Wang, G. (2000). Interaction of $\mathrm{CO}_{2}$ enrichment and drought on growth, water use, and yield of broad bean (Vicia faba). Environmental and Experimental Botany, 43, 131-139, ISSN 0098-8472 
Yang, S., Vanderbeld, B., Wan, J. \& Huang, Y. (2010). Narrowing down the targets: Towards successful genetic engineering of drought-tolerant crops. Molecular Plant, 3, 469490, ISSN 1674-2052

Ziska, L. H. (2008). Three year field evaluation of early and late 20th century spring wheat lines to projected increases in atmospheric carbon dioxide. Field Crops Research, 108, 54-59, ISSN 0378-4290 